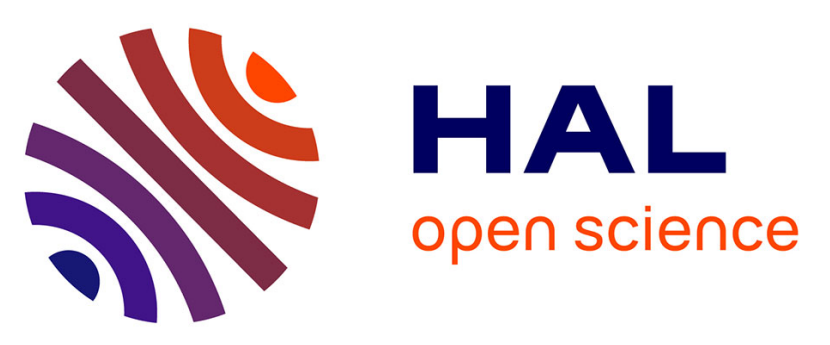

\title{
Valorization of Calcium Carbonate-Based Solid Wastes for the Treatment of Hydrogen Sulfide from the Gas Phase
}

Huynh Pham Xuan, Doan Pham Minh, Marta Galera Martinez, Ange Nzihou, Patrick Sharrock

\section{To cite this version:}

Huynh Pham Xuan, Doan Pham Minh, Marta Galera Martinez, Ange Nzihou, Patrick Sharrock. Valorization of Calcium Carbonate-Based Solid Wastes for the Treatment of Hydrogen Sulfide from the Gas Phase. Industrial and engineering chemistry research, 2015, pp.1-27. 10.1021/acs.iecr.5b00764 . hal-01150082

\section{HAL Id: hal-01150082 \\ https://hal.science/hal-01150082}

Submitted on 8 May 2015

HAL is a multi-disciplinary open access archive for the deposit and dissemination of scientific research documents, whether they are published or not. The documents may come from teaching and research institutions in France or abroad, or from public or private research centers.
L'archive ouverte pluridisciplinaire HAL, est destinée au dépôt et à la diffusion de documents scientifiques de niveau recherche, publiés ou non, émanant des établissements d'enseignement et de recherche français ou étrangers, des laboratoires publics ou privés.

\section{(1)(1) $\$(0)$}

Distributed under a Creative Commons Attribution - NonCommercial - ShareAlikel 4.0 


\section{Article}

\section{Valorization of calcium carbonate-based solid wastes for the treatment of hydrogen sulfide from gas phase}

Huynh Pham Xuan, Doan PHAM MINH, Marta Galera-Martinez, Ange Nzihou, and Patrick Sharrock

Ind. Eng. Chem. Res., Just Accepted Manuscript • DOI: 10.1021/acs.iecr.5b00764 • Publication Date (Web): 23 Apr 2015

Downloaded from http://pubs.acs.org on April 28, 2015

\section{Just Accepted}

"Just Accepted" manuscripts have been peer-reviewed and accepted for publication. They are posted online prior to technical editing, formatting for publication and author proofing. The American Chemical Society provides "Just Accepted" as a free service to the research community to expedite the dissemination of scientific material as soon as possible after acceptance. "Just Accepted" manuscripts appear in full in PDF format accompanied by an HTML abstract. "Just Accepted" manuscripts have been fully peer reviewed, but should not be considered the official version of record. They are accessible to all readers and citable by the Digital Object Identifier (DOI®). "Just Accepted" is an optional service offered to authors. Therefore, the "Just Accepted" Web site may not include all articles that will be published in the journal. After a manuscript is technically edited and formatted, it will be removed from the "Just Accepted" Web site and published as an ASAP article. Note that technical editing may introduce minor changes to the manuscript text and/or graphics which could affect content, and all legal disclaimers and ethical guidelines that apply to the journal pertain. ACS cannot be held responsible for errors or consequences arising from the use of information contained in these "Just Accepted" manuscripts. 


\title{
Valorization of calcium carbonate-based solid
}

\section{wastes for the treatment of hydrogen sulfide from}

\author{
gas phase
}

\author{
Huynh PHAM XUAN, Doan PHAM MINH*', Marta GALERA MARTINEZ, Ange NZIHOU, \\ Patrick SHARROCK \\ Université de Toulouse, Mines Albi, CNRS UMR 5302, Centre RAPSODEE, Campus Jarlard, \\ F-81013 Albi cedex 09, France
}

KEYWORDS: Solvay process ${ }^{\circledR}$, solid waste, calcium carbonate, $\mathrm{H}_{2} \mathrm{~S}$ removal, regeneration

\begin{abstract}
:
This paper focuses on the valorization of calcium carbonate-based solid wastes for the removal of hydrogen sulfide from gas phase. Two solid wastes taken from industrial sites for the production of sodium carbonate and sodium bicarbonate by the Solvay process ${ }^{\circledR}$ were analyzed by different physico-chemical methods. Calcium carbonate was found as the main component of both the solid wastes. Trace amounts of other elements such as $\mathrm{Mg}, \mathrm{Al}, \mathrm{Fe}, \mathrm{Si}, \mathrm{Cl}, \mathrm{Na}$ etc. were

\footnotetext{
* Corresponding author. Email: doan.phamminh@mines-albi.fr. Tel: +33563493258. Fax: $+33563493243$
} 
also present in these wastes. These solid wastes showed higher sorption activity for the removal of $\mathrm{H}_{2} \mathrm{~S}$, compared to a pure commercial calcium carbonate. The contact time was found as an important parameter for the complete $\mathrm{H}_{2} \mathrm{~S}$ uptake. The addition of well-dispersed iron-based particles could be carried out by the standard incipient wetness impregnation method. Sorbent containing $1 \mathrm{wt} . \%$ of spiked iron had the similar sorption behavior compared to a commercial activated carbon, in terms of reactivity and reactivation possibility.

\section{Introduction}

Sodium bicarbonate $\left(\mathrm{NaHCO}_{3}\right)$ and sodium carbonate $\left(\mathrm{Na}_{2} \mathrm{CO}_{3}\right)$ are widely used in different applications. ${ }^{[1]}$ They can be used as melting agent in glass and metallurgy industries. They can be used as alkaline reactant in different processes, for the neutralization of acid gas, or for the synthesis of sodium salts such as sodium phosphates, sodium nitrate, sodium chromate, sodium citrate. Other fields of application of sodium carbonate and sodium bicarbonate may be listed as follows: detergence, steel industry, pharmaceutical, paper mill, water softening, food industry, and many others. Discovered and developed by Ernest Solvay during the 1860s, the Solvay process ${ }^{\circledR}$ became the main process for the fabrication of sodium carbonate and sodium bicarbonate from limestone $\left(\mathrm{CaCO}_{3}\right)$ and salt brine $(\mathrm{NaCl})$ as the starting materials. ${ }^{[2]}$ This process can be summarized by the following steps: ${ }^{[1]}$

- Step 1: Preparation of a saturated aqueous solution of $\mathrm{NaCl}$ (brine).

- Step 2: Saturation of this brine with $\mathrm{NH}_{3}$ to form an ammoniated brine $\left(\mathrm{H}_{2} \mathrm{O}, \mathrm{NaCl}\right.$ and $\mathrm{NH}_{3(\mathrm{aq})}$ ).

- Step 3: Calcination of limestone :

$$
\mathrm{CaCO}_{3} \rightarrow \mathrm{CaO}+\mathrm{CO}_{2}
$$

- Step 4: Preparation of lime milk : 
$\mathrm{CaO}+\mathrm{H}_{2} \mathrm{O} \rightarrow \mathrm{Ca}(\mathrm{OH})_{2}$

- Step 5: Carbonation of the ammoniated brine with $\mathrm{CO}_{2}$ recovered from Step 3. Ammonium bicarbonate is formed (Eq. 3), followed by the double decomposition of sodium chloride and ammonium bicarbonate to form sodium bicarbonate (Eq. 4)

$$
\mathrm{NH}_{3(\mathrm{aq})}+\mathrm{H}_{2} \mathrm{O}+\mathrm{CO}_{2} \rightarrow \mathrm{NH}_{4} \mathrm{HCO}_{3}
$$

$$
\mathrm{NH}_{4} \mathrm{HCO}_{3}+\mathrm{NaCl} \rightarrow \mathrm{NH}_{4} \mathrm{Cl}+\mathrm{NaHCO}_{3}
$$

- Step 6: Sodium bicarbonate, which is less soluble, is filtered from the solution.

- Step 7: Thermal decomposition of sodium bicarbonate to form sodium carbonate at about $150-200^{\circ} \mathrm{C}$ :

$$
2 \mathrm{NaHCO}_{3} \rightarrow \mathrm{CO}_{2}+\mathrm{Na}_{2} \mathrm{CO}_{3}+\mathrm{H}_{2} \mathrm{O}
$$

- Step 8: Regeneration of $\mathrm{NH}_{3}$ from lime milk (Step 4) and $\mathrm{NH}_{4} \mathrm{Cl}$ (Step 5):

$$
2 \mathrm{NH}_{4} \mathrm{Cl}+\mathrm{Ca}(\mathrm{OH})_{2} \rightarrow 2 \mathrm{NH}_{4} \mathrm{OH}+\mathrm{CaCl}_{2}
$$

The global equation of this process is the following:

$$
2 \mathrm{NaCl}+\mathrm{CaCO}_{3} \rightarrow \mathrm{Na}_{2} \mathrm{CO}_{3}+\mathrm{CaCl}_{2}
$$

The key step of this process is the carbonation of the ammoniated brine and the crystallization of $\mathrm{NaHCO}_{3}$, where the yield reaches generally about $70-75 \%$ for the transformation from $\mathrm{NaCl}$ to $\mathrm{NaHCO}_{3}$. The liquid phase (filtrate) generated from Step 6 contains large amounts of $\mathrm{NH}_{4} \mathrm{HCO}_{3},\left(\mathrm{NH}_{4}\right)_{2} \mathrm{CO}_{3}, \mathrm{NaHCO}_{3}, \mathrm{NH}_{4} \mathrm{Cl}$ and $\mathrm{NaCl}$, which are soluble in water. ${ }^{[3]}$ Thus, during the generation of $\mathrm{NH}_{3}$ using lime milk (Step 8), a precipitate which contains mainly calcium carbonate (called hereafter PCC) is formed. Taking into account the annual production of sodium carbonate and sodium bicarbonate by the Solvay process ${ }^{\circledR}$ of about 55 millions of tons worldwide (in 2011), ${ }^{[4]}$ large quantities of PCC are generated annually. Upto-date, PCC is considered as a by-product and is directly discharged around the production site 
or to the sea. However, environmental preservation and production appear as one of the most important challenge of the XXI century. As indicated by the waste management hierarchy, ${ }^{[5]}$ the most favored option for waste management is its prevention, followed by its minimization, its reuse, its recycling, its energy recovery and its disposal.

This work aims to investigate the reuse of two PCC generated by two different sites of Solvay process ${ }^{\circledR}$ for the development of new and low cost sorbents for the treatment of hydrogen sulfide in the gas phase. As we can see later, PCC contains mainly calcium carbonate, but also significant contents of metals such as iron, magnesium, sodium etc. Calcium carbonate, with its basicity, and with the presence of various metals may be favorable for the fixation of hydrogen sulfide $\left(\mathrm{H}_{2} \mathrm{~S}\right) .{ }^{[6-8]} \mathrm{H}_{2} \mathrm{~S}$ is formed as gas pollutant in different processes such as coal combustion, petrochemical processing, fermentation of biomass or gasification of coal/biomass for generating syngas etc. ${ }^{[9-11]}$ The efficient removal of $\mathrm{H}_{2} \mathrm{~S}$ usually appears as the crucial step for a given process. For example, syngas produced from gasification of biomass has to be purified and the total amounts of $\mathrm{H}_{2} \mathrm{~S}$ and COS must be less than $20,20,1$ and $0.01 \mathrm{mg} \mathrm{Nm}^{-3}$ for engine, turbine, methanol synthesis and Fisher-Tropsch synthesis applications, respectively. ${ }^{[12-13]}$

2. Materials and methods

2.1. Chemical and physico-chemical analyses

Different chemical and physico-chemical techniques were used for analyzing sorbents before test of $\mathrm{H}_{2} \mathrm{~S}$ removal. Thermogravimetry (TG) was performed with a SDTQ600 analyzer (TA Instruments) at a heating rate of $5^{\circ} \mathrm{C} / \mathrm{min}$ under air flux $(100 \mathrm{~mL} / \mathrm{min})$. X-ray diffraction (XRD) data of the solids were collected using a Phillips Panalytical X'pert Pro MPD diffractometer with a $\mathrm{Cu} \mathrm{K \alpha}(1.543 \AA)$ radiation source. Scanning electron microscopy (SEM) was carried out on a Philips XL30 ESEM apparatus (FEI Company) which was coupled with an energy-dispersive X- 
ray spectroscopy (EDX analysis). Specific surface area was determined by BET method, using a MICROMERITICS Gemini Vacprep 061). X-ray fluorescence (XRF) was carried out with a PANanalytical (Epsilon E3 XL). Inductively coupled plasma atomic emission spectroscopy (ICP-AES) using a HORIBA Jobin-Yvon Ultima 2. The $\mathrm{pH}_{\mathrm{pzc}}$ was determined according to Pham Minh et al. ${ }^{[14]}$ Calcination experiments as pretreatment of sorbents were done in a static muffle-furnace (Nabertherm P320). For each calcination, about $5 \mathrm{~g}$ of solid was introduced in a ceramic open dish. This last one was then placed in the furnace. The furnace was heated by means of $20^{\circ} \mathrm{C} \min ^{-1}$ up to the desired temperature $\left(105\right.$ to $\left.850^{\circ} \mathrm{C}\right)$, and was kept at this final temperature for $2 \mathrm{~h}$. Then, the furnace was freely cooled down to room temperature. The calcined solid was immediately used for all further characterization and tests.

\subsection{Sorbents}

Two PCC sources were used in this study. The first one was sampled from the Solvay factory at Dombasle-sur-Meurthe (France), which is designated thereafter PCC-F. The second one was taken from the Solvay factory at Torrelavega (Spain), which is called thereafter $P C C-S$. Both PCC were in fine powder form. They were firstly dried at room temperature (ca. $20^{\circ} \mathrm{C}$ ) up to constant weight. Then, they were sieved to eliminate particles bigger than $315 \mu \mathrm{m}$. In fact, the fraction of particles larger than $315 \mu \mathrm{m}$ represented only less than 1 wt.\% of both PCC. The fraction of particles smaller than $315 \mu \mathrm{m}$ was thermally treated by calcination at $105-850{ }^{\circ} \mathrm{C}$ before sorption test.

Pure calcite powder $\left(\mathrm{CaCO}_{3},>98\right.$ wt.\%) from Fisher Scientific, and commercial activated carbon (L3S from CECA, France, $900 \mathrm{~m}^{2} \mathrm{~g}^{-1}$ ) in powder form were used as the reference sorbents. They are designated thereafter "Calcite" and "AC" for pure calcite and activated carbon, respectively. This pure calcite was also treated by calcination at $105-850^{\circ} \mathrm{C}$ before 
sorption test in order to compare with calcined PCC-F and PCC-S. AC was used as received, without further pretreatment.

\subsection{Sorption test}

The tests of $\mathrm{H}_{2} \mathrm{~S}$ removal were carried out at room temperature (ca. $20^{\circ} \mathrm{C}$ ) and ambient pressure using a glass fixed-bed reactor. Figure 1 shows the scheme of the reactor used. This reactor (length $60 \mathrm{~mm}$, internal diameter $11 \mathrm{~mm}$ ) was equipped with a porous glass disc which allowed keeping the sorbent bed, and the passage of gas through the sorbent bed. The volume of sorbent bed varied from about 1.5 to $3.2 \mathrm{~cm}^{3}$, corresponding to the apparent density and the amount of sorbent used for each experiment (0.5 to $1.0 \mathrm{~g})$. A synthetic waste gas, based on dried air and containing 50 ppmv of $\mathrm{H}_{2} \mathrm{~S}$ passed through the sorbent bed with a flow rate of $50 \mathrm{~mL}$ $\min ^{-1}$ and was controlled by a flow meter. The output $\mathrm{H}_{2} \mathrm{~S}$ concentration was monitored every 5 seconds using a gas analyser from BW Technologies (Gas Alert QUATTRO). Sorption experiments were stopped when the sorbent was saturated or when the rate of $\mathrm{H}_{2} \mathrm{~S}$ sorption slowed down.

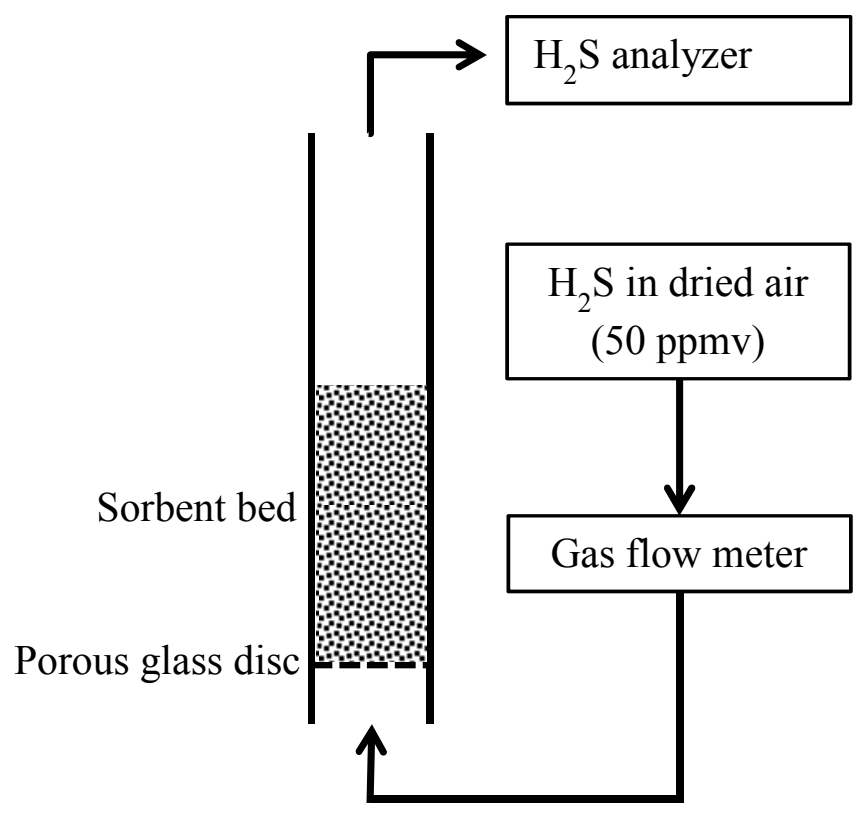

Figure 1. Scheme of the reactor used in this work. 
In this paper, the following terms are used in order to compare different sorbents and different experimental conditions:

- $H_{2} S_{\text {Input }}(\mathrm{mg})$ : the total accumulated quantity of $\mathrm{H}_{2} \mathrm{~S}$ injected to the reactor at a given reaction time.

- Accumulated $_{\text {Sorbent }}(\mathrm{mg})$ : the total accumulated quantity of $\mathrm{H}_{2} \mathrm{~S}$ fixed on the sorbent at a given reaction time.

- $t_{100 \%}(\mathrm{~min})$ : the reaction time wherein the removal of $\mathrm{H}_{2} \mathrm{~S}$ was total. So, theoretically $\mathrm{H}_{2} \mathrm{~S}_{\text {Input }}$ is equal to Accumulated Sorbent $_{\text {with }} t_{100 \%}$.

The amount of $\mathrm{H}_{2} \mathrm{~S}_{\text {Input }}$ and Accumulated Sorbent $_{\text {was }}$ calculated with the Eqs. (8) and (9), respectively:

$$
\begin{aligned}
& H_{2} S_{\text {Input }}=\frac{P Q M}{10^{6} R T} C_{\text {int }} t \\
& \text { Accumulated }_{\text {Sorbent }}=\frac{P Q M}{10^{6} R T}\left[C_{\text {int }} t-\int_{0}^{t} C_{\text {out }} d t\right]
\end{aligned}
$$

where $Q$ : inlet flow rate $\left(\mathrm{L} \mathrm{min}^{-1}\right), M$ : the molecular weight of $\mathrm{H}_{2} \mathrm{~S}\left(34.06 \mathrm{~g} \mathrm{~mol}^{-1}\right), W$ : mass of sorbent used (g), $C_{i n}$ : inlet concentration of $\mathrm{H}_{2} \mathrm{~S}(50 \mathrm{ppmv}), C_{\text {out }}$ : outlet concentration of $\mathrm{H}_{2} \mathrm{~S}$ (ppmv), $t$ : reaction time (min).

3. Results and discussion

3.1. Analysis and characterisation of the sorbents before test 
a. Elemental analysis of the initial PCC

Elemental analysis of the initial PCC was carried out by XRF and ICP-AES techniques. Table 1 shows the main elements of both initial PCC-F and PCC-S. Calcium carbonate was found as the main compound of both solid wastes. Other elements were also present, including different metals, sulphur and chlorine. The content of organic compounds was negligible.

Table 1. Elemental analyses of both FCC-F and FCC-S dried at room temperature.

\begin{tabular}{|l|l|l|l|l|l|l|l|l|l|}
\hline Compounds & $\mathrm{CaCO}_{3}$ & $\mathrm{Mg}$ & $\mathrm{Al}$ & $\mathrm{Si}$ & $\mathrm{Fe}$ & $\mathrm{S}$ & $\mathrm{Cl}$ & $\mathrm{Na}$ & Others* \\
\hline FCC-F, wt. \% & 98 & 0.6 & 0.2 & 0.5 & 0.5 & 0.2 & 0.1 & 0.4 & 0.5 \\
\hline FCC-S, wt.\% & 97 & 0.7 & 0.2 & 0.6 & 0.3 & 0.6 & 0.5 & Trace & 0.3 \\
\hline
\end{tabular}

(* P, Cu, Mn, Zn, Sn)

b. Thermogravimetric analysis

Figure 2 shows TG curves of different FCC-F solids, which were previously calcined at different temperatures. Small weight losses between 350 and $580{ }^{\circ} \mathrm{C}$ were observed for the solids pretreated at 20,105 and $200{ }^{\circ} \mathrm{C}$. The main weight loss starting at $580-780{ }^{\circ} \mathrm{C}$ was due to the decarbonation of calcium carbonate. This weight loss represent $42.8-43.7$ wt.\% for the solids pretreated at $20-580^{\circ} \mathrm{C}$, which means that FCC-F contains mainly calcium carbonate (theoretical weight loss of pure calcium carbonate being 44 wt.\%). This confirms again the results of elemental analyses. The calcination at $700{ }^{\circ} \mathrm{C}$ for $2 \mathrm{~h}$ in a static furnace did not allow the complete decarbonation of calcium carbonate because the weight loss at $580-780{ }^{\circ} \mathrm{C}$ of this solid reached again 35.3 wt.\% on second thermal treatment in TG analyzer. On the other hand, for the 
solid preatreated at $850{ }^{\circ} \mathrm{C}$, the decarbonation was complete after $2 \mathrm{~h}$. Previous studies showed that the kinetic of calcite calcination depends on the particle size and the atmosphere of calcination. ${ }^{[15]}$ These results were also found for FCC-S and commercial pure calcite, pretreated at different temperatures (results not shown here).

Because of the thermal decomposition of calcium carbonate, starting above $580{ }^{\circ} \mathrm{C}$, we studied only the sorption activity of the sorbents which were thermally treated at $580{ }^{\circ} \mathrm{C}$ and below.

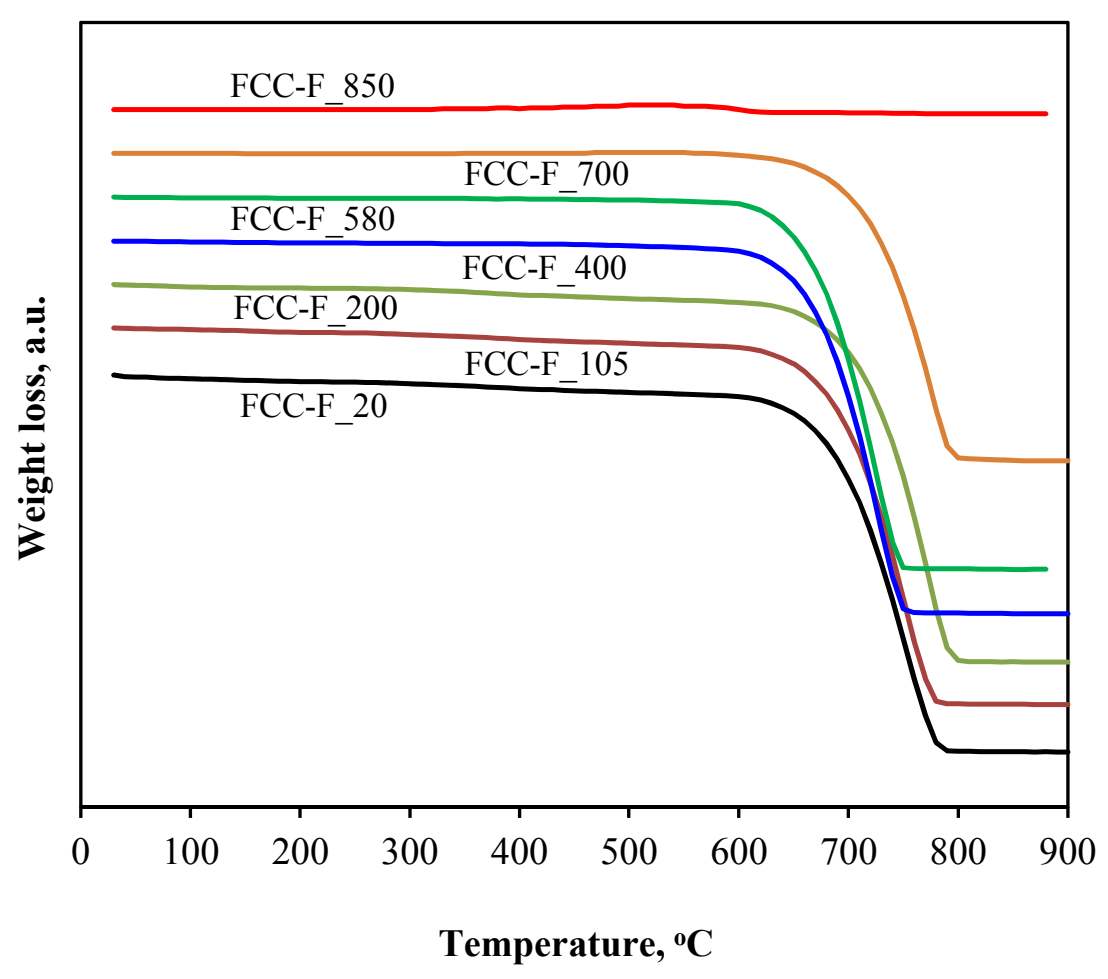

Figure 2. TG curves of the FCC-F after thermal treatment at different temperatures.

c. XRD and specific surface area

Figure 3 shows XRD results of FCC-F after thermal treatment at different temperatures. All diffraction peaks could be attributed to calcite, which was found as the only main crystalline 
phase of this solid waste. The solid powder dried at ambient condition was already highly crystalline. Thus, the calcination step up to $580{ }^{\circ} \mathrm{C}$ did not significantly modify its crystallinity. These results confirmed TG analyses above. And the similar results were obtained with FCC-S and commercial pure calcite (results not shown).

All three initial calcite based sorbents (FCC-F, FCC-S, pure calcite) had the specific surface area lower than $3 \mathrm{~m}^{2} \mathrm{~g}^{-1}$.

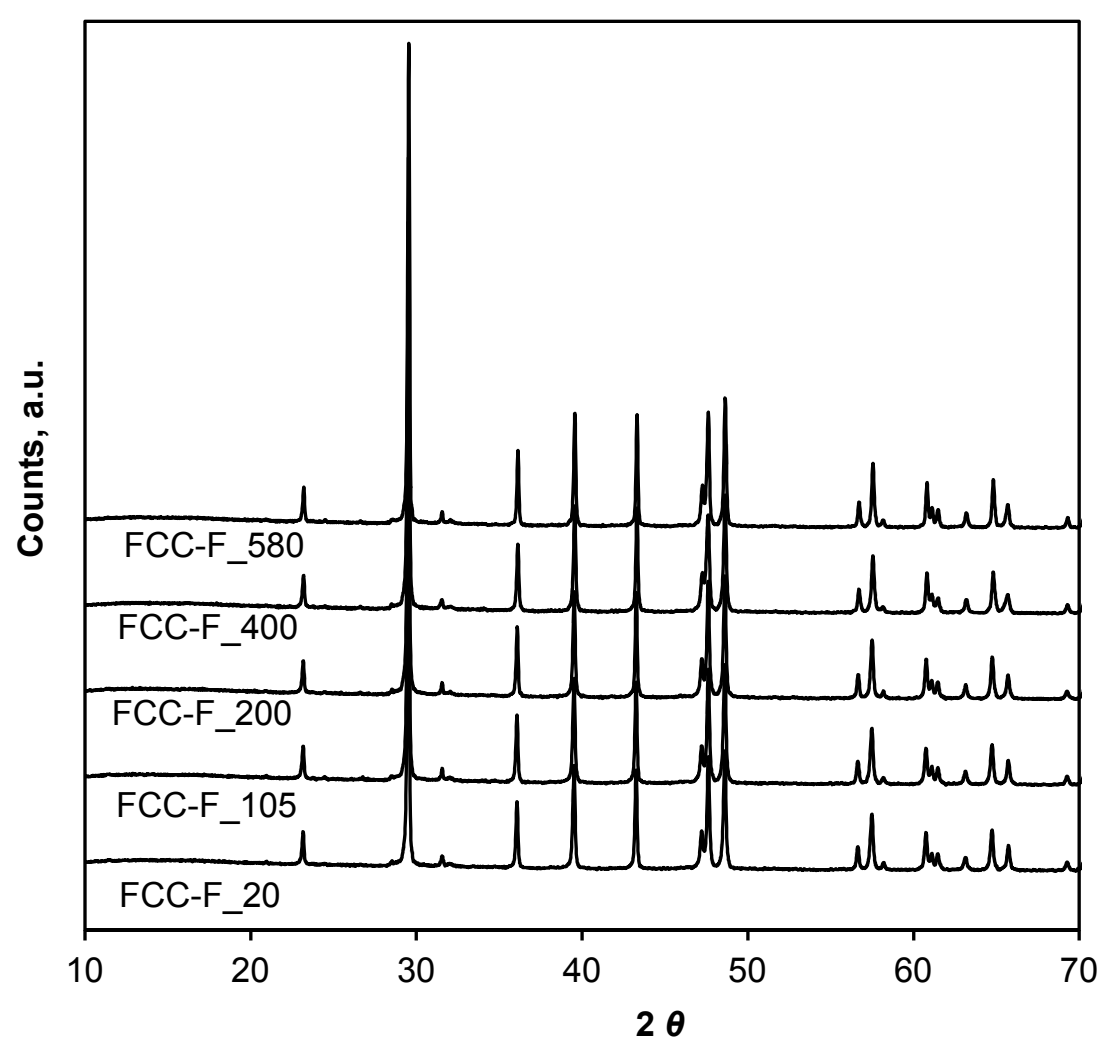

Figure 3. XRD patterns of the FCC-F after thermal treatment at different temperatures.

\subsection{Sorption activity of the sorbents}

The reactivity of the different sorbents was investigated at ambient condition. Figures 4-6 show the results obtained with FCC-F, FCC-S and pure calcite based sorbents, respectively. For each figure, the Input curve represents the accumulated quantity of $\mathrm{H}_{2} \mathrm{~S}$ introduced into the 
reactor. Other curves represent the accumulated quantity of $\mathrm{H}_{2} \mathrm{~S}$, which was fixed by the sorbents.

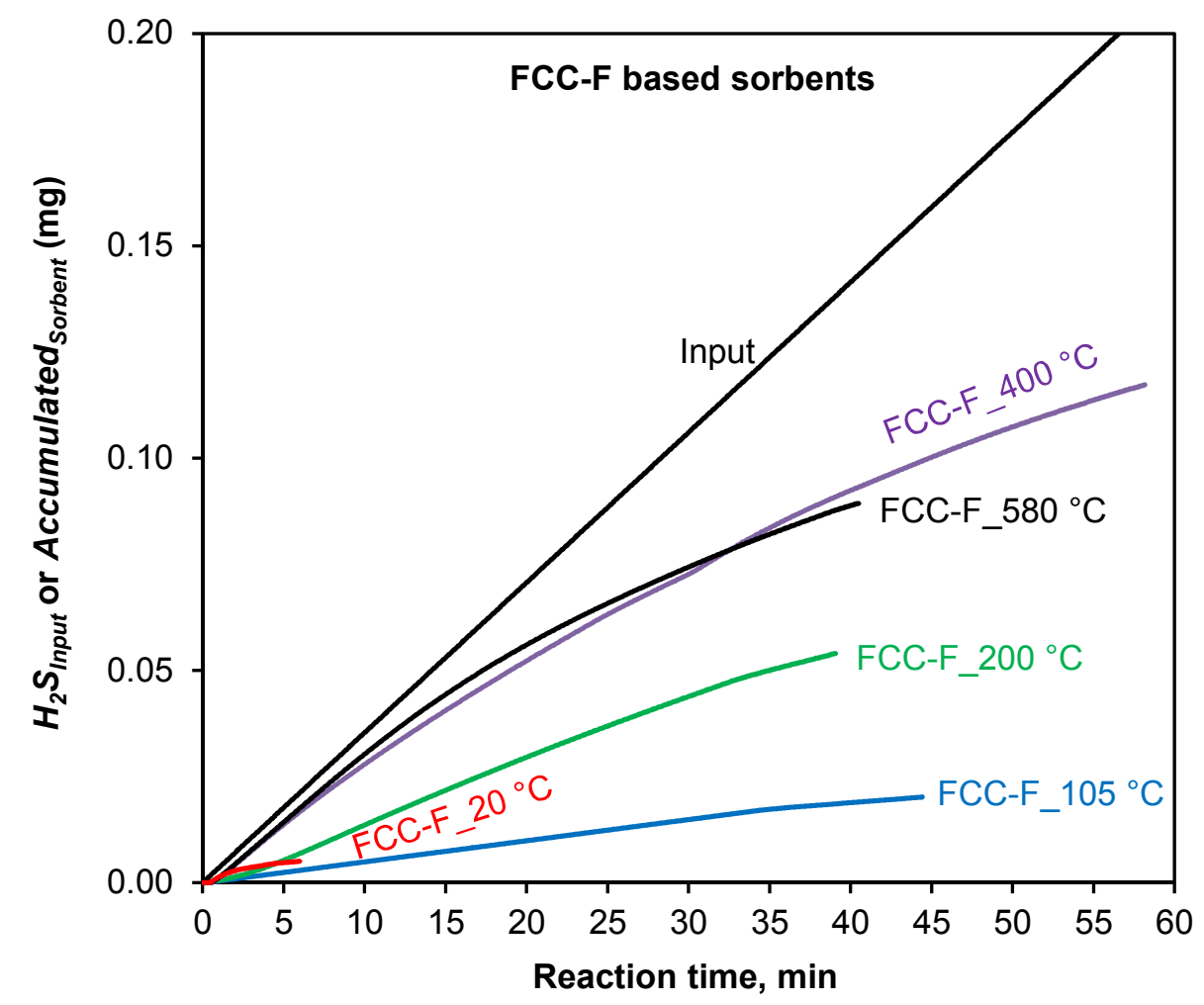

Figure 4. Quantity of the accumulated $\mathrm{H}_{2} \mathrm{~S}$ fed into the reactor (Input curve) and remaining after passing over FCC-F based sorbents. The sorbent were pre-treated by calcination at different temperatures. Sorption conditions: $50 \mathrm{ppmv}$ of $\mathrm{H}_{2} \mathrm{~S}$ in dried air, $50 \mathrm{~mL} \mathrm{~min}^{-1}, 0.5 \mathrm{~g}$ of sorbent, room temperature and pressure.

For FCC-F based sorbents, the sorption performance increased with the calcination temperature up to $400{ }^{\circ} \mathrm{C}$ (Figure 4). The sorbents calcined at 400 and $580{ }^{\circ} \mathrm{C}$ had the similar reactivity. Thermal treatment is known as an efficient treatment for desorbing molecules adsorbed on the surface of a given solid, as well as for the combustion of eventual organic molecules present in the initial sorbents. Thus, calcined solid with clean surface is more appropriate for the fixation of $\mathrm{H}_{2} \mathrm{~S}$. In addition, the thermal treatment allows transforming 
carbonates of metals such as iron, sodium, magnesium etc. which were present in this solid waste, into the corresponding metal oxides. These last ones may have higher affinity for $\mathrm{H}_{2} \mathrm{~S}$ fixation.

When the calcination temperature rose to $580{ }^{\circ} \mathrm{C}$, no further physico-chemical transformation took place, compared to $400{ }^{\circ} \mathrm{C}$, as indicated by TG analysis (Figure 2). This may explain the similar reactivity of the two sorbents calcined at 400 and $580{ }^{\circ} \mathrm{C}$. Taking into account the energy consumed for the calcination step, the pre-treatment at $400{ }^{\circ} \mathrm{C}$ was the most efficient.

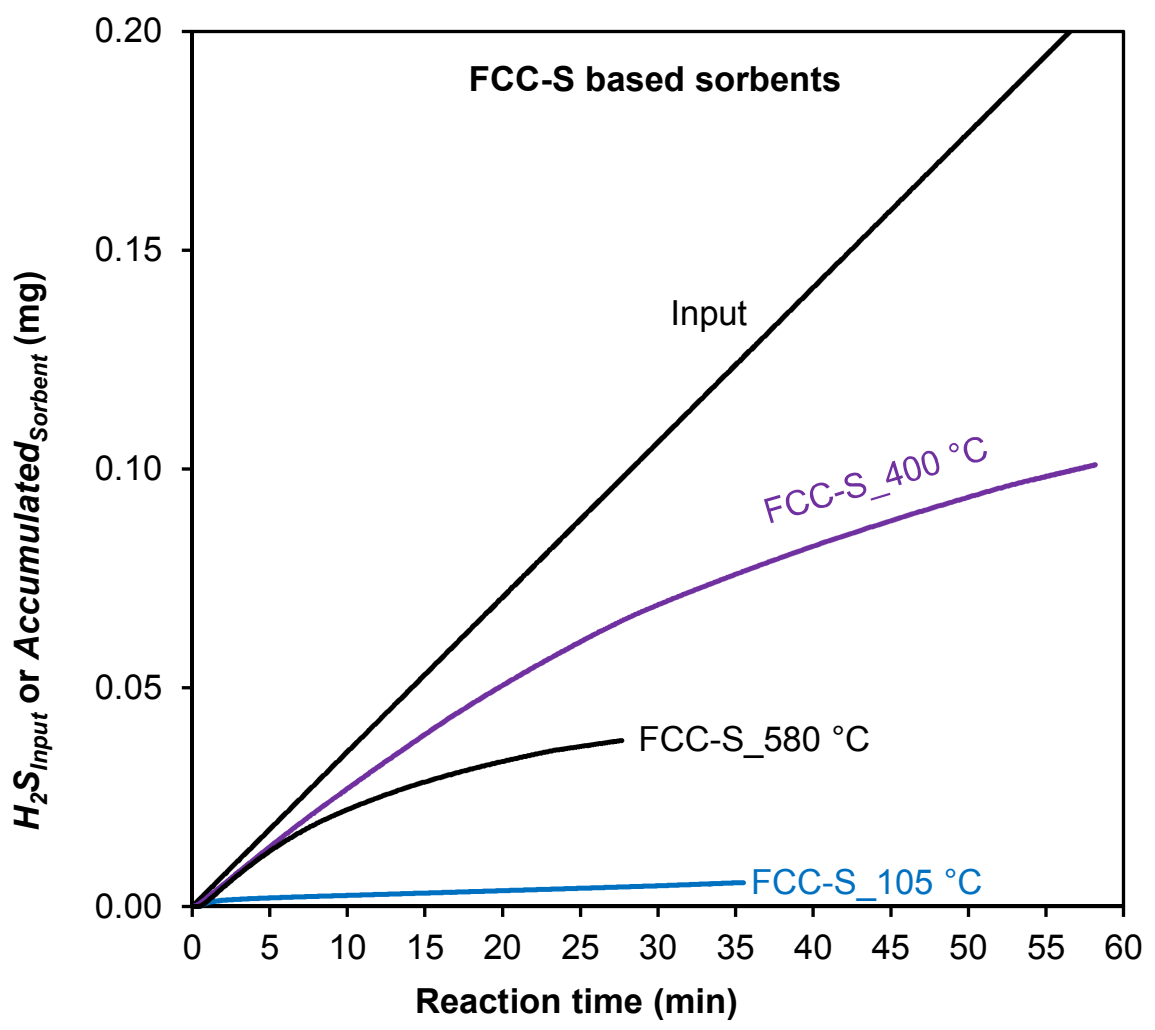

Figure 5. Quantity of the accumulated $\mathrm{H}_{2} \mathrm{~S}$ fed into the reactor (Input curve) and remaining after passing over FCC-S based sorbents. The sorbents were pre-treated by calcination at different

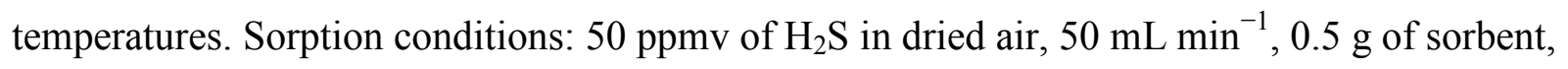
room temperature and pressure. 
Figure 5 shows the results obtained with FCC-S based sorbents. As previously observed with FCC-F based sorbents, the reactivity of FCC-S treated at $105{ }^{\circ} \mathrm{C}$ was smaller than that of the solids treated at 400 and $580{ }^{\circ} \mathrm{C}$. Both the solids calcined at 400 and $580{ }^{\circ} \mathrm{C}$ had the similar sorption behaviour during the first 6 min of time-on-stream. Then, the sorbent treated at $580{ }^{\circ} \mathrm{C}$ was saturated more quickly than the one treated at $400{ }^{\circ} \mathrm{C}$. This behaviour was also observed for the sorbents starting from pure commercial calcite (Figure 6). Standard characterizations such as TG-DSC, SEM, IR, XRD did not reveal the differences between these calcined solids.

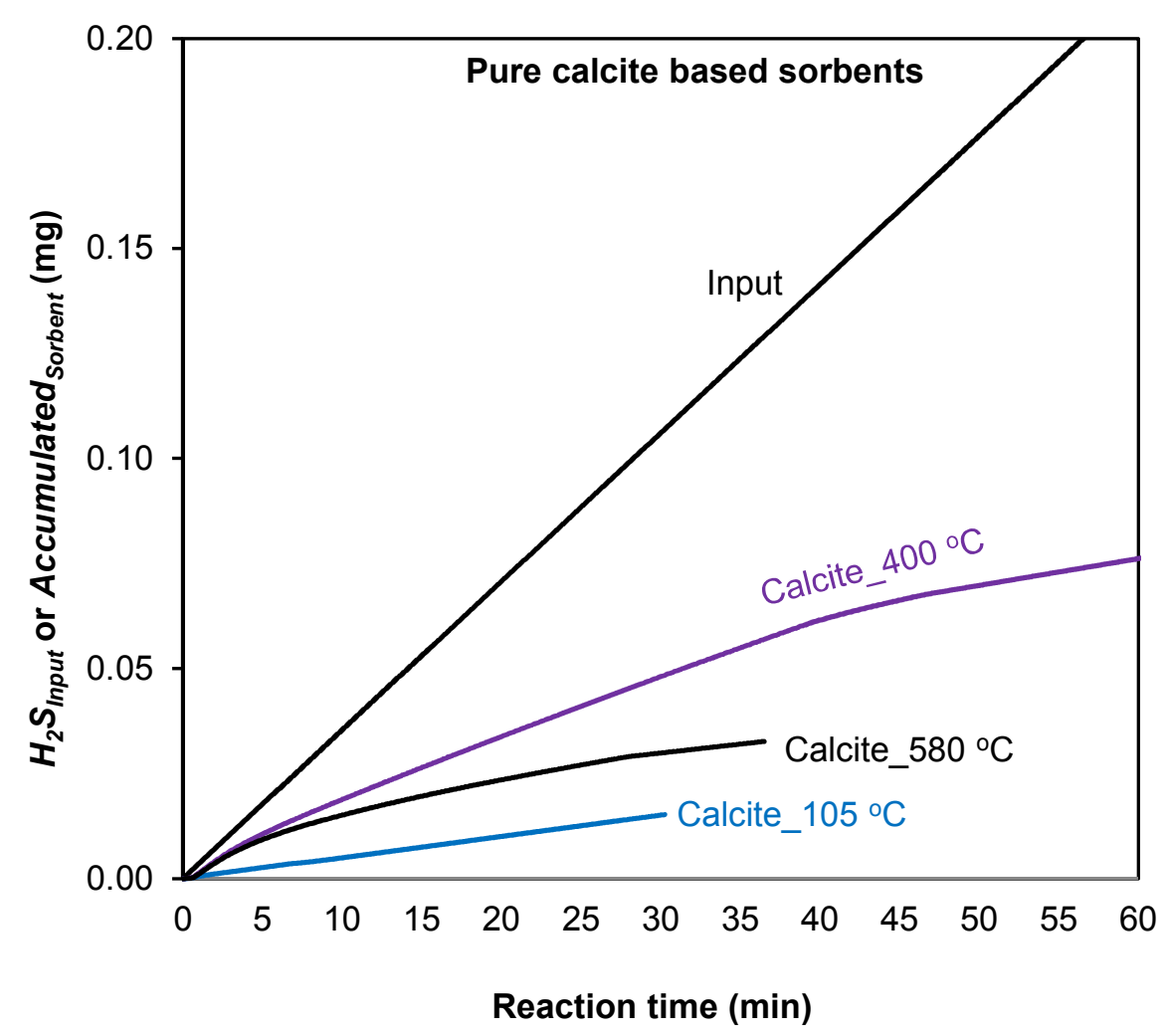

Figure 6. Quantity of the accumulated $\mathrm{H}_{2} \mathrm{~S}$ fed into the reactor (Input curve) and remaining after passing over the pure calcite based sorbents. The sorbents were pre-treated by calcination at different temperatures. Sorption conditions: $50 \mathrm{ppmv}$ of $\mathrm{H}_{2} \mathrm{~S}$ in dried air, $50 \mathrm{~mL} \mathrm{~min}{ }^{-1}, 0.5 \mathrm{~g}$ of sorbent, room temperature and pressure. 
From the results in Figures 4-6, the calcination at $400{ }^{\circ} \mathrm{C}$ seemed to be the most suitable pretreatment of both the solid wastes. The comparison of the reactivity of three sorbents, calcined at $400{ }^{\circ} \mathrm{C}$, shows that both the solid wastes were more active than the pure calcite (Figure 7). This was probably due to the presence of various impurities in the solid wastes, as reported in Table 1. Metals oxides such as iron, copper, zinc oxides, are well known as active phase for $\mathrm{H}_{2} \mathrm{~S}$ fixation. ${ }^{[16-18]}$ Further study is necessary for understanding the transformation of impurities present in the initial FCC during calcination step, and their role for $\mathrm{H}_{2} \mathrm{~S}$ removal.

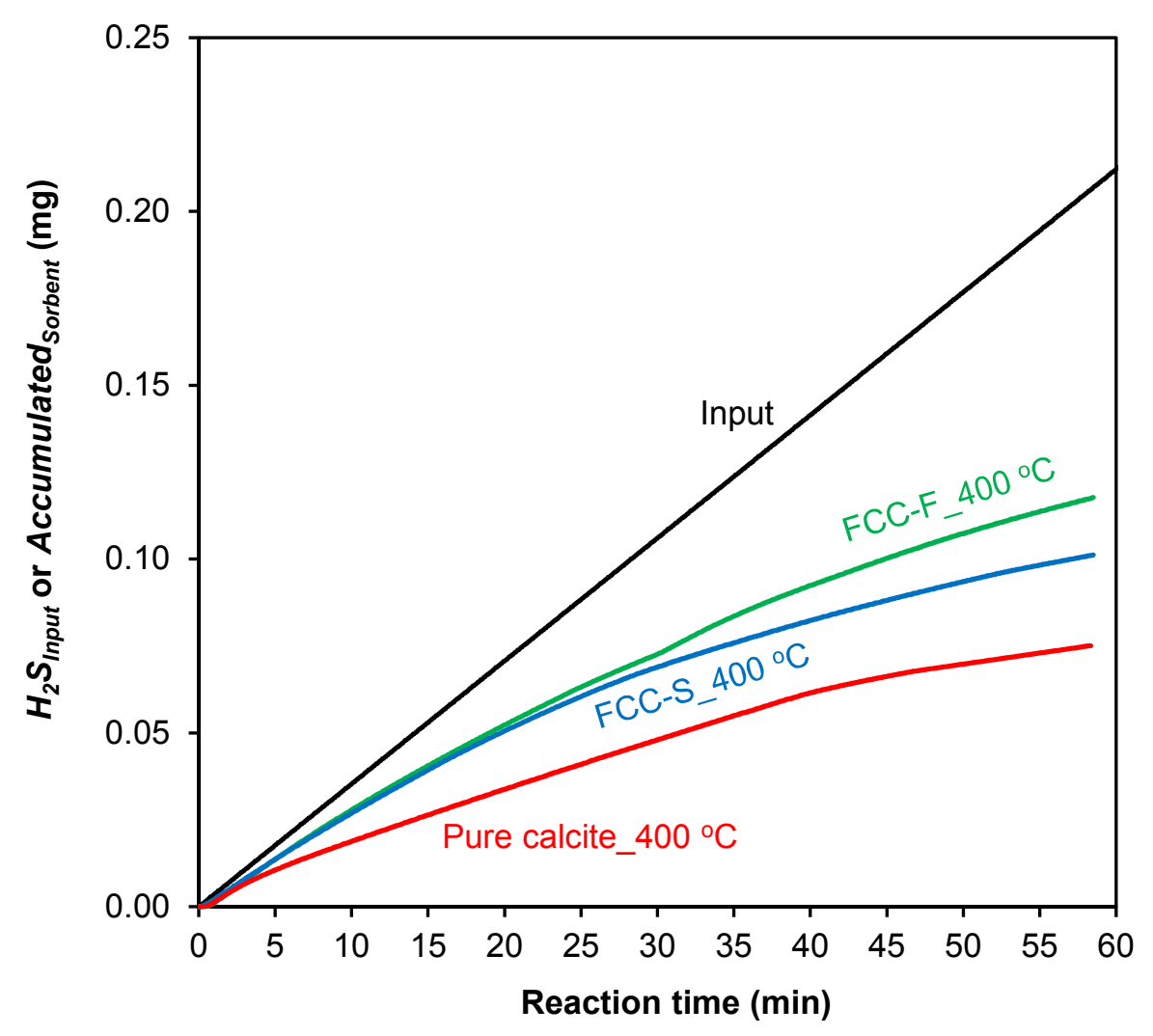

Figure 7. Comparison of three sorbents treated at $400{ }^{\circ} \mathrm{C}$. Sorption conditions: 50 ppmv of $\mathrm{H}_{2} \mathrm{~S}$

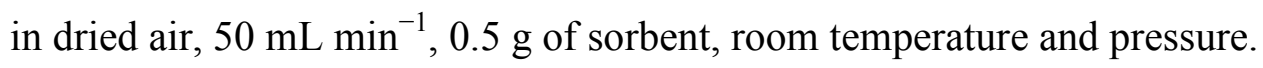

\subsection{Influence of the contact time}




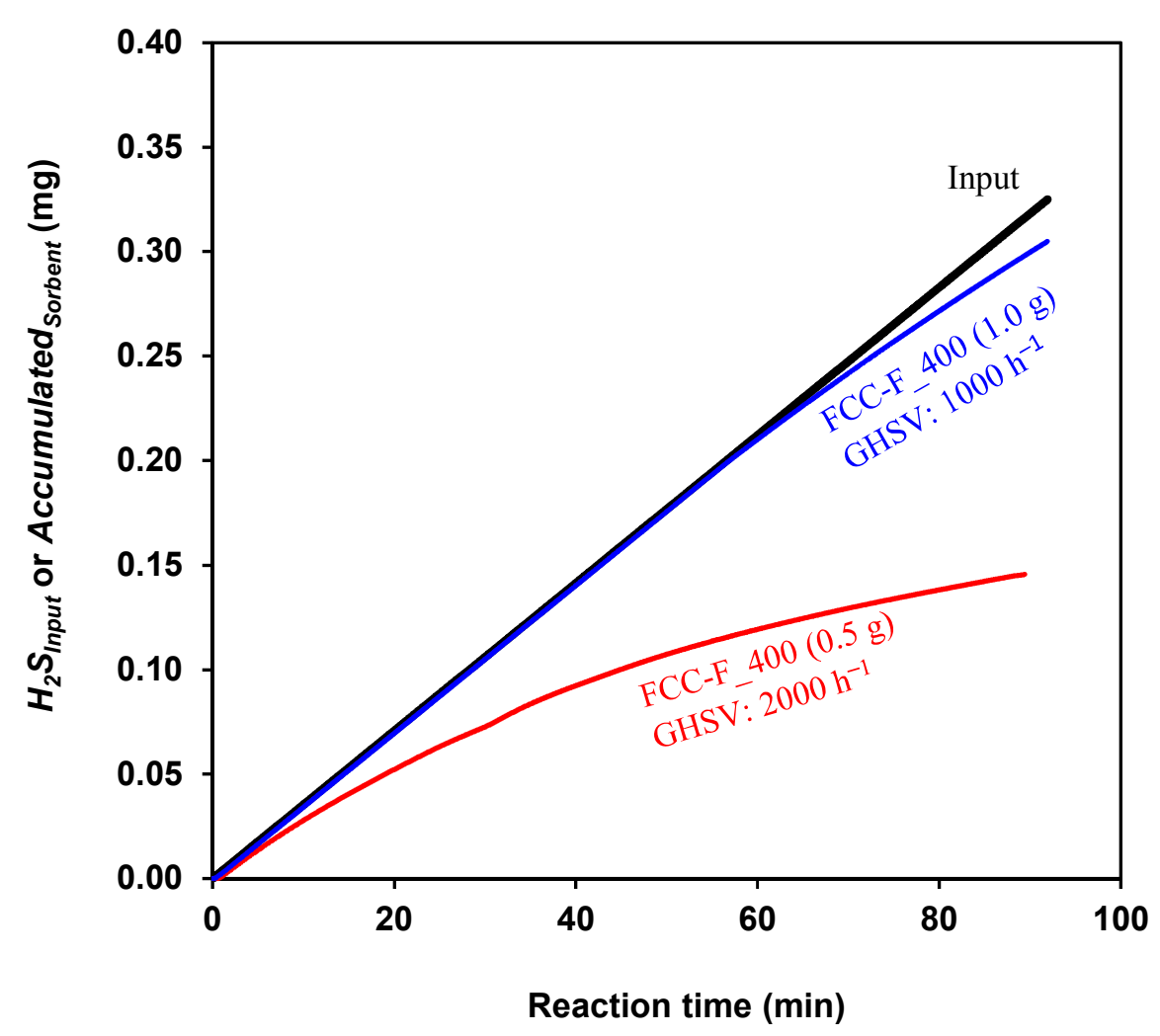

Figure 8. Influence of the contact time on the performance of the process using FCC-F pretreated at $400{ }^{\circ} \mathrm{C}$. Sorption conditions: $50 \mathrm{ppmv}$ of $\mathrm{H}_{2} \mathrm{~S}$ in dried air, $50 \mathrm{~mL} \mathrm{~min}{ }^{-1}, 0.5$ to $1.0 \mathrm{~g}$ of sorbent, room temperature and pressure.

Taking into account the apparent volume of the solid bed of $1.5 \mathrm{~mL}$ for $0.5 \mathrm{~g}$ of FCC-F or FCC-S, the corresponding gas hourly space velocity used (GHSV) was equal to $2000 \mathrm{~h}^{-1}$. At this GHSV, despite the encouraging results presented above, neither the solid wastes nor pure calcite were good enough for the effective removal of $\mathrm{H}_{2} \mathrm{~S}$. In fact, $t_{100 \%}$ never exceeded 3 min for all the sorbents treated at various temperatures. In order to enhance the sorption performance, the quantity of the sorbent FCC-F_400 was doubled while keeping unchanged the gas flow rate. Figure 8 show the results obtained. The increase of the sorbent quantity improved strongly the performance of $\mathrm{H}_{2} \mathrm{~S}$ removal. The value of $t_{100 \%}$ reached up to $55 \mathrm{~min}$ at the GHSV of $1000 \mathrm{~h}^{-1}$. 
So, the contact time was found to be a crucial parameter for the purification of trace amounts of $\mathrm{H}_{2} \mathrm{~S}$ in dry air.

\subsection{Influence of iron addition}

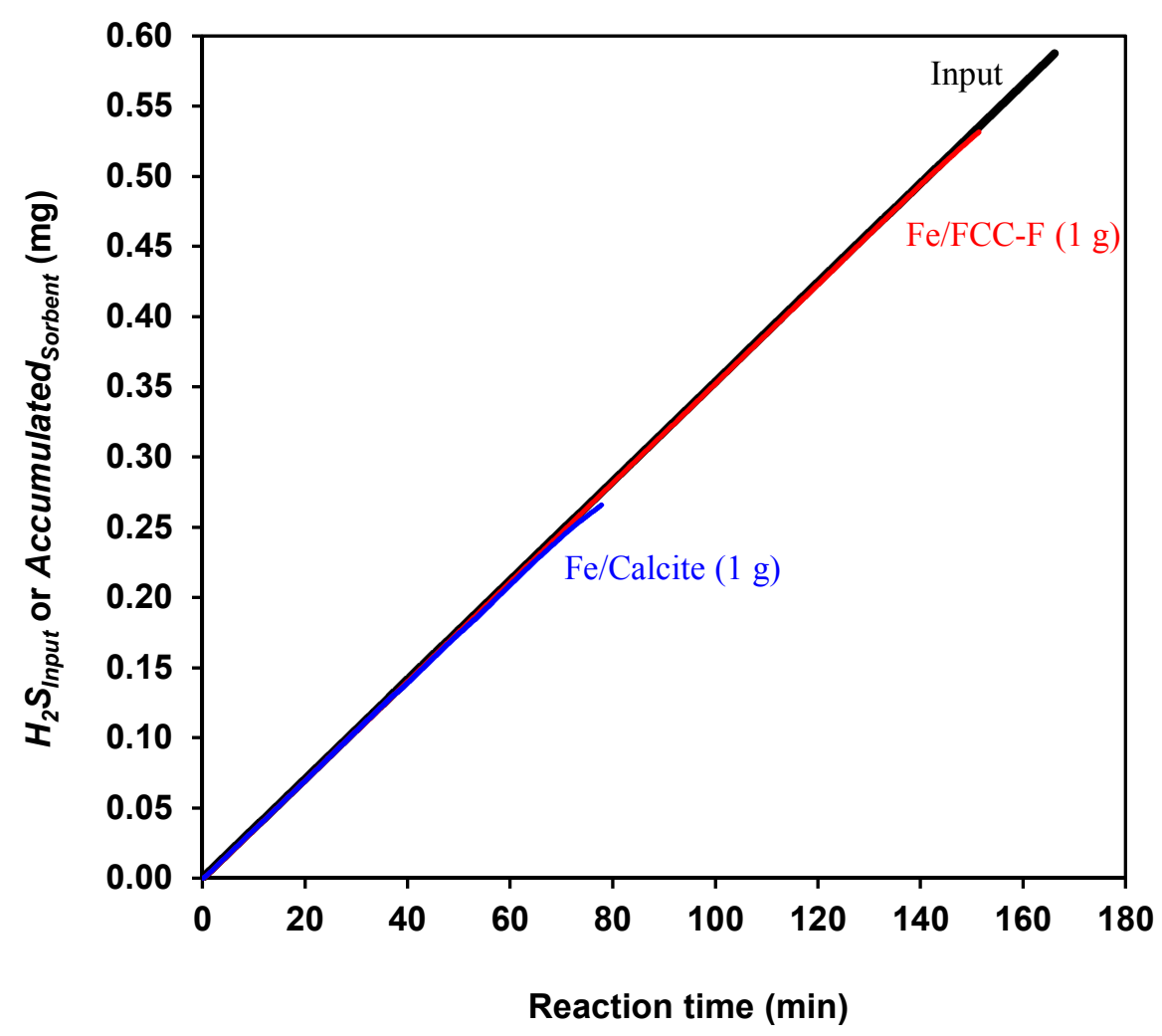

Figure 9. Sorption behavior of iron-doped sorbents. Sorption conditions: 50 ppmv of $\mathrm{H}_{2} \mathrm{~S}$ in dried air, $50 \mathrm{~mL} \mathrm{~min}^{-1}, 1.0 \mathrm{~g}$ of sorbent, room temperature and pressure.

The improvement of the performance of a sorbent can also be realized by the addition of highly-dispersed metal-based particles, which have high affinity for $\mathrm{H}_{2} \mathrm{~S}$ immobilization. ${ }^{[19-20]}$ In this study, we chosen iron as the metal active because of its low cost, its availability and its high potential reactivity for $\mathrm{H}_{2} \mathrm{~S}$ removal. ${ }^{[21-22]}$ FCC-F and pure calcite were used as supports for the dispersion of iron particles. Iron particles deposition was carried out using the standard incipient wetness impregnation method, as described elsewhere. ${ }^{[23-24]}$ An aqueous solution of $\mathrm{Fe}\left(\mathrm{NO}_{3}\right)_{3}$ 
was added to FCC-F or pure calcite powder in order to wet just enough the outer and pore surfaces of the support material. The concentration of $\mathrm{Fe}\left(\mathrm{NO}_{3}\right)_{3}$ solution was calculed to reach finally 1 wt.\% of iron in the final solid sorbent, which was either Fe/FCC-F or Fe/Calcite. The iron content was chosen at $1 \mathrm{wt} . \%$ according to the low specific surface area of FCC-F and pure calcite. After the impregnation step, the solid was dried overnight at $105^{\circ} \mathrm{C}$ and calcined at 500 ${ }^{\circ} \mathrm{C}$ under air before use in $\mathrm{H}_{2} \mathrm{~S}$ sorption experiment.

Figure 9 shows the sorption behavior of iron-doped sorbents. Firstly, the addition of iron particles to FCC-F solid led to the considerable improvement of its sorption performance. Its $t_{100 \%}$ reached 150 min, which was much higher than $t_{100 \%}$ of the undoped FCC-F (55 min, Figure 8) under the same sorption conditions. Secondly, using the same preparation method for the deposition of iron particles, FCC-F based sorbent (Fe/FCC-F) was more active than pure calcite based sorbent (Fe/Calcite), which had $t_{100 \%}$ equal to 150 and $70 \mathrm{~min}$, respectively. SEM analysis allowed observing the formation of iron-based particles on the surface of these two supports (Figure 10). These particles had higher contrast compared to the surface of the supports, as confirmed by EDX analysis (results not shown). We can see that iron-based particles formed on the surface Fe/FCC-F were smaller than those formed on the surface of Fe/Calcite. In addition, the phenomenon of local agglomeration of iron particles was observed for Fe/Calcite, but was not the case for Fe/FCC-F. In fact, the $\mathrm{pH}_{\mathrm{pzc}}$ was 8.5 and 9.9 for FCC-F dried at room temperature, and for commercial calcite, respectively. Commercial calcite, with higher $\mathrm{pH}_{\mathrm{pzc}}$, led to the local and rapid precipitation of iron oxides during the addition of aqueous solution of $\mathrm{Fe}\left(\mathrm{NO}_{3}\right)_{3}$ on its surface. On the other hand, FCC-F solid waste, with lower $\mathrm{pH}_{\mathrm{pzc}}$, prevented or limited this local precipitation of iron oxides. 

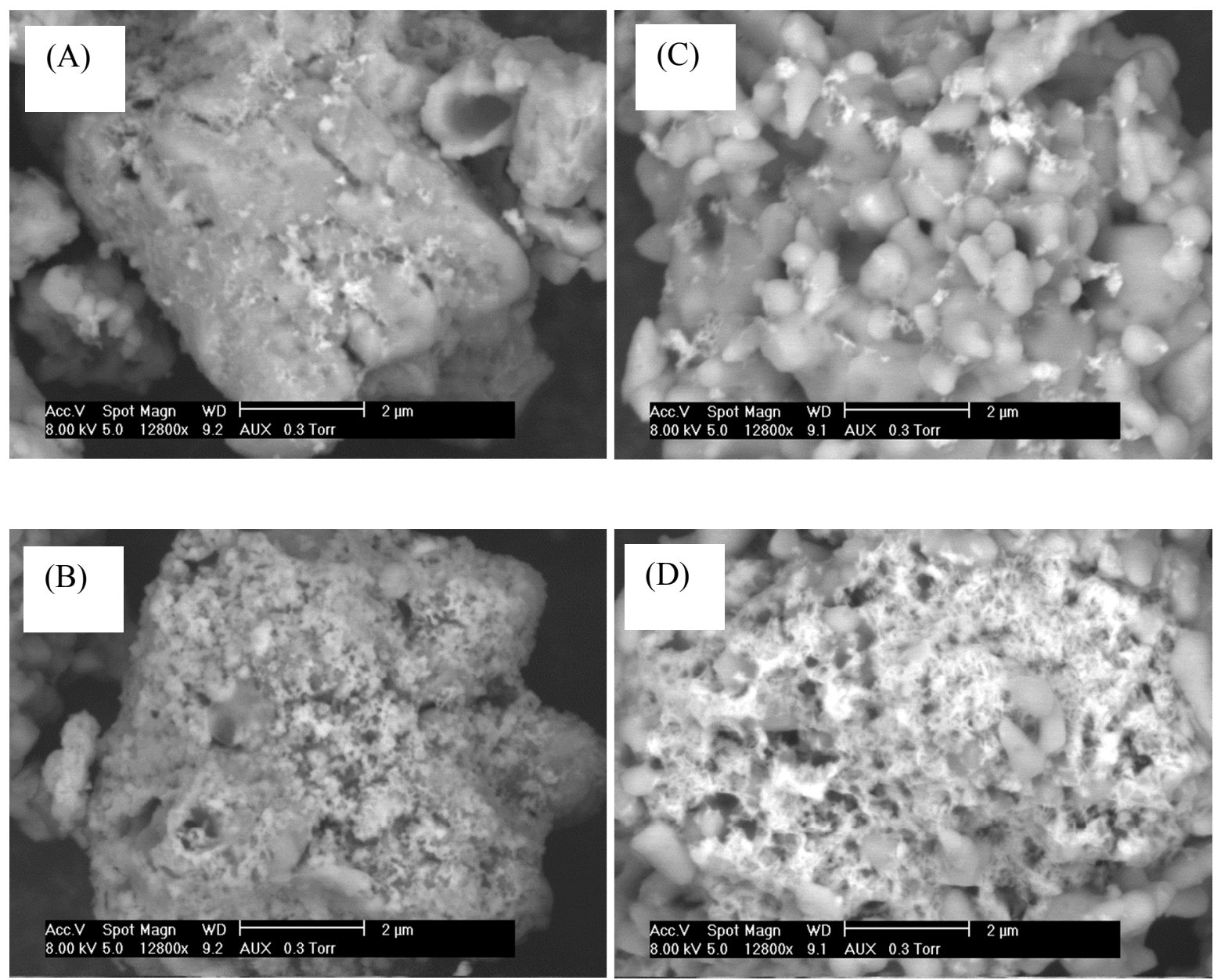

Figure 10. SEM analysis of Fe/FCC-F (A, B) and Fe/Calcite (C, D).

\subsection{Comparison with an activated carbon}

Activated carbon is considered as the reference sorbent for gas treatment, in particular in the case of $\mathrm{H}_{2} \mathrm{~S}$ treatment. In this study, the reactivity of the undoped FCC-F_400 and the iron-doped sorbent (Fe/FCC-F) was compared with that of an activated carbon purchased from CECA (France, L3S model), which is specially designed for $\mathrm{H}_{2} \mathrm{~S}$ treatment. Figure 11 shows the results obtained. FCC-F solid waste doped with 1 wt.\% of iron (Fe/FCC-F) was slightly more active than the activated carbon. The value of $t_{100 \%}$ reached around 55 and $60 \mathrm{~min}$ for the activated carbon and Fe/FCC-F, respectively, when $0.5 \mathrm{~g}$ sorbent were used. By doubling the quantity of 
the undoped sorbent FCC-F_400, the equivalent sorption performance compared to Fe/FCC-F or the activated carbon could be also obtained. This observation appeared as a major result because FCC-F and FCC-S are currently considered as solid wastes and need to be treated inside the industrial sites of the Solvay process ${ }^{\circledR}$.

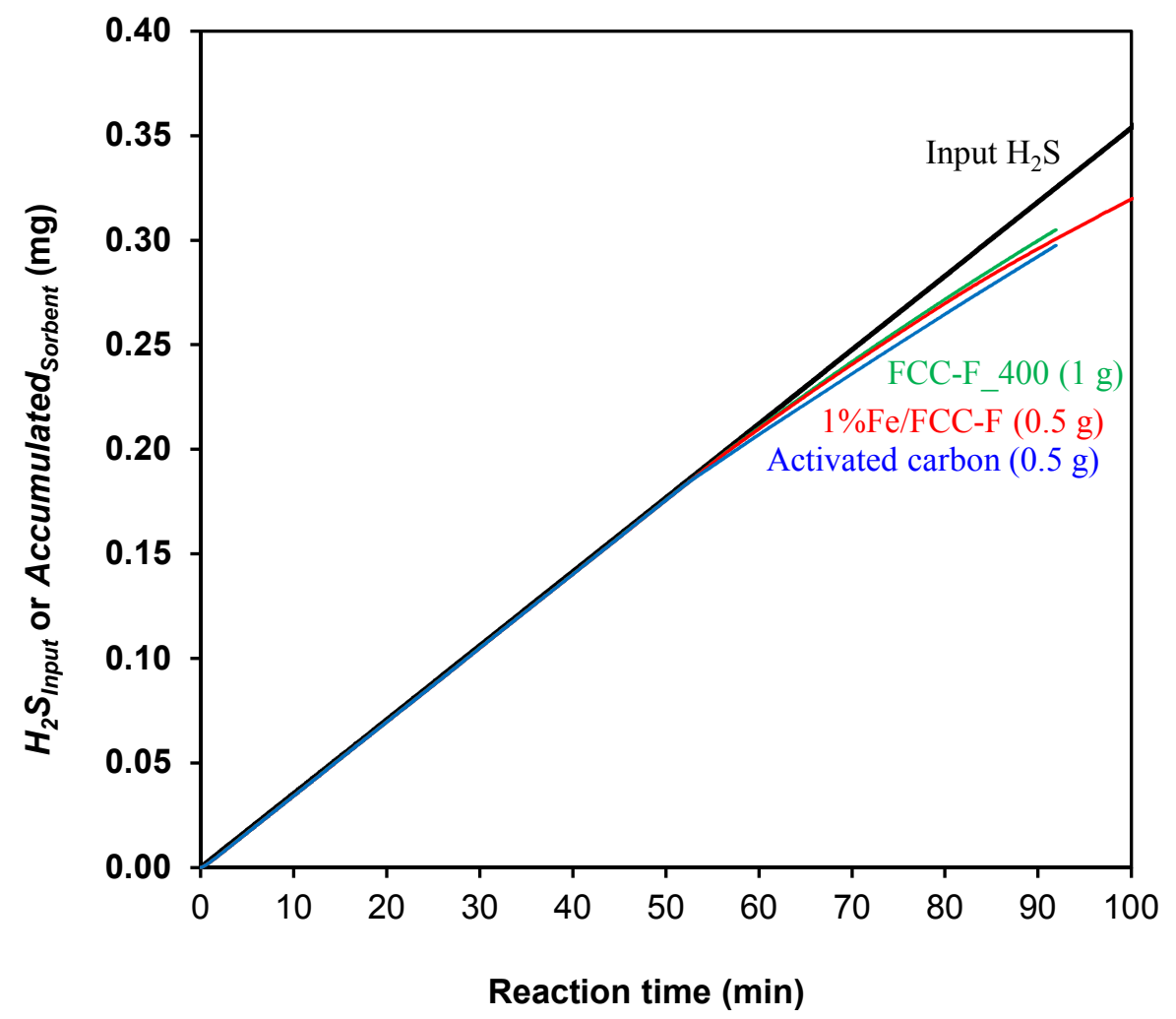

Figure 11. Comparison of the activity of FCC-F based sorbents and an activated carbon as reference. Sorption conditions: 50 ppmv of $\mathrm{H}_{2} \mathrm{~S}$ in dried air, $50 \mathrm{~mL} \mathrm{~min}^{-1}, 0.5$ to $1.0 \mathrm{~g}$ of sorbent, room temperature and pressure.

\subsection{Recycling tests}

The higher reactivity of both the solid wastes compared to the pure commercial calcite and the considerable improvement of the reactivity of FCC-F sorbent by adding iron particles on its surface suggest that metals and metal oxides are probably active sites for the fixation of $\mathrm{H}_{2} \mathrm{~S}$, in addition to the basicity of calcium carbonate's surface. The fixation of $\mathrm{H}_{2} \mathrm{~S}$ may relate to the 
adsorption by physisorption interaction, or by chemisorption; this last one is generally not reversible. To verify the reutilization possibility of the used sorbent, desorption test by thermal treatment was tested. The used sorbent was heated at $500{ }^{\circ} \mathrm{C}$ for $2 \mathrm{~h}$ before the first recycling test. The desorption was repeated again for the second recycling. Figure 12 shows the results obtained with undoped FCC-F, and with iron-doped FCC-F sorbents. For the undoped sorbent (Figure $12 \mathrm{~A}$ ); $t_{100 \%}$ decreased from about $60 \mathrm{~min}$ to $30 \mathrm{~min}$ at the first recycling, and to $12 \mathrm{~min}$ at the second recycling. For the iron-doped sorbent (Figure $12 \mathrm{~B}$ ), its $t_{100 \%}$ decreased from about $150 \mathrm{~min}$ to $45 \mathrm{~min}$ at the first recycling and to $25 \mathrm{~min}$ at the second recycling. The partial loss of reactivity during thermal reactivation of used sorbent has commonly been observed for other kinds of sorbents, such as activated carbon. ${ }^{[25-27]}$ This reactivity loss might be due irreversible interaction between $\mathrm{H}_{2} \mathrm{~S}$ and metal oxides. This loss might be also due to the oxidation of $\mathrm{H}_{2} \mathrm{~S}$ to nonvolatile sulfur compounds. ${ }^{[28]}$ This might be also due to the agglomeration of active sites during the regeneration by heating at $500{ }^{\circ} \mathrm{C}$. The agglomeration of active sites is known as irreversible deactivation. Further analysis is needed for determining sulfur compounds formed during $\mathrm{H}_{2} \mathrm{~S}$ removal and for understanding the reason of this irreversible deactivation. 


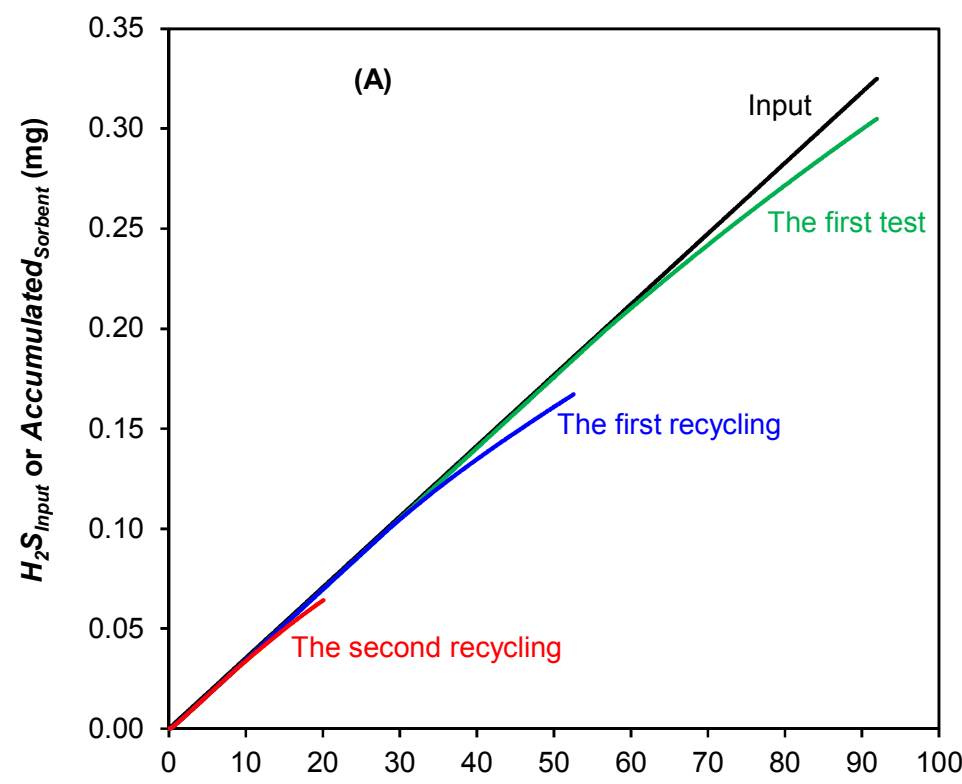

Reaction time (min)

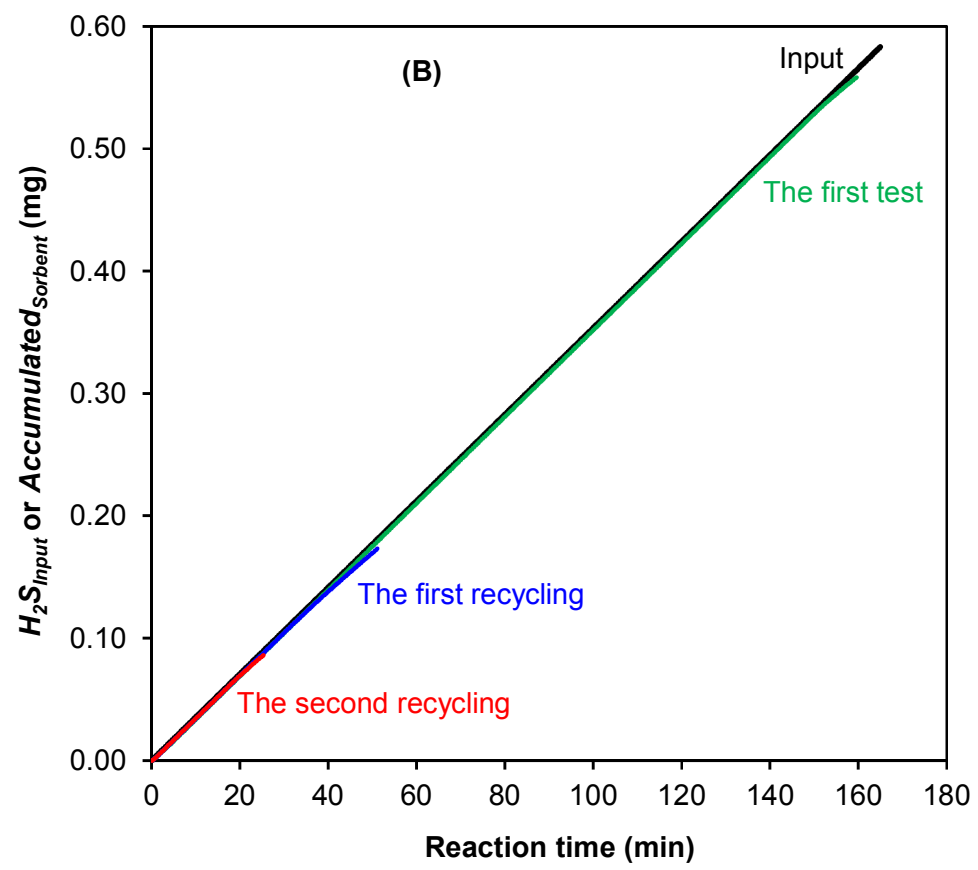

Figure 12. Regeneration of used sorbent; (A) undoped FCC-F_400; (B) iron-doped sorbent (Fe/FCC-F); Regeneration conditions: heating at $500{ }^{\circ} \mathrm{C}$ for $2 \mathrm{~h}$ under air atmosphere; Sorption conditions: 50 ppmv of $\mathrm{H}_{2} \mathrm{~S}$ in dried air, $50 \mathrm{~mL} \mathrm{~min}^{-1}, 1.0 \mathrm{~g}$ of sorbent, room temperature and pressure. 


\section{Conclusions}

Sorption behavior of two calcium carbonate based solid wastes, which were recovered from industrial sites of the Solvay process ${ }^{\circledR}$, was investigated for the treatment of $\mathrm{H}_{2} \mathrm{~S}$ in gas phase. The sorbents generated from these solid wastes, by simple thermal pre-treatment or by addition of only 1 wt.\% of iron, showed equivalent reactivity compared to an activated carbon. The results open new prospects for the valorization of calcium carbonate-based solid wastes for environmental purposes.

Acknowledgment: The authors gratefully acknowledge colleagues at the RAPSODEE centre for technical help. We thank Mr. Patrick Perrin from Solvay Group for offering the solid wastes.

Figure and Table captions

Figure 1. Scheme of the reactor used in this work.

Figure 2. TG curves of the FCC-F after thermal treatment at different temperatures.

Figure 3. XRD patterns of the FCC-F after thermal treatment at different temperatures.

Figure 4. Quantity of the accumulated $\mathrm{H}_{2} \mathrm{~S}$ fed into the reactor (Input curve) and remaining after passing over FCC-F based sorbents. The sorbent were pre-treated by calcination at different temperatures. Sorption conditions: $50 \mathrm{ppmv}$ of $\mathrm{H}_{2} \mathrm{~S}$ in dried air, $50 \mathrm{~mL} \mathrm{~min}{ }^{-1}, 0.5 \mathrm{~g}$ of sorbent, room temperature and pressure.

Figure 5. Quantity of the accumulated $\mathrm{H}_{2} \mathrm{~S}$ fed into the reactor (Input curve) and remaining after passing over FCC-S based sorbents. The sorbents were pre-treated by calcination at different temperatures. Sorption conditions: 50 ppmv of $\mathrm{H}_{2} \mathrm{~S}$ in dried air, $50 \mathrm{~mL} \mathrm{~min}{ }^{-1}, 0.5 \mathrm{~g}$ of sorbent, room temperature and pressure. 
Figure 6. Quantity of the accumulated $\mathrm{H}_{2} \mathrm{~S}$ fed into the reactor (Input curve) and remaining after passing over the pure calcite based sorbents. The sorbents were pre-treated by calcination at different temperatures. Sorption conditions: 50 ppmv of $\mathrm{H}_{2} \mathrm{~S}$ in dried air, $50 \mathrm{~mL} \mathrm{~min}{ }^{-1}, 0.5 \mathrm{~g}$ of sorbent, room temperature and pressure.

Figure 7. Comparison of three sorbents treated at $400{ }^{\circ} \mathrm{C}$. Sorption conditions: 50 ppmv of $\mathrm{H}_{2} \mathrm{~S}$

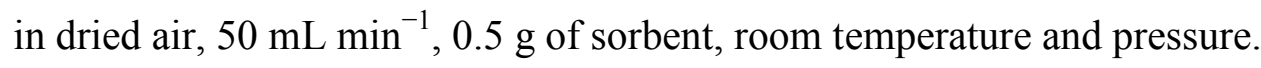

Figure 8. Influence of the contact time on the performance of the process using FCC-F pretreated at $400{ }^{\circ} \mathrm{C}$. Sorption conditions: $50 \mathrm{ppmv}$ of $\mathrm{H}_{2} \mathrm{~S}$ in dried air, $50 \mathrm{~mL} \mathrm{~min}{ }^{-1}, 0.5$ to $1.0 \mathrm{~g}$ of sorbent, room temperature and pressure.

Figure 9. Sorption behavior of iron-doped sorbents. Sorption conditions: $50 \mathrm{ppmv}$ of $\mathrm{H}_{2} \mathrm{~S}$ in

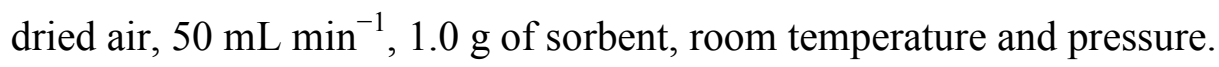

Figure 10. SEM analysis of Fe/FCC-F (A, B) and Fe/Calcite (C, D).

Figure 11. Comparison of the activity of FCC-F based sorbents and an activated carbon as reference. Sorption conditions: 50 ppmv of $\mathrm{H}_{2} \mathrm{~S}$ in dried air, $50 \mathrm{~mL} \mathrm{~min}{ }^{-1}, 0.5$ to $1.0 \mathrm{~g}$ of sorbent, room temperature and pressure.

Figure 12. Regeneration of used sorbent; (A) undoped FCC-F_400; (B) iron-doped sorbent (Fe/FCC-F); Regeneration conditions: heating at $500{ }^{\circ} \mathrm{C}$ for $2 \mathrm{~h}$ under air atmosphere; Sorption conditions: 50 ppmv of $\mathrm{H}_{2} \mathrm{~S}$ in dried air, $50 \mathrm{~mL} \mathrm{~min}^{-1}, 1.0 \mathrm{~g}$ of sorbent, room temperature and pressure.

Table 1. Elemental analyses of both FCC-F and FCC-S dried at room temperature. 
References

(1) Breton, C. Carbonate de sodium - Procédé Solvay à l'ammoniac. Techniques de l'ingénieur 2002, j6195.

(2) Ernest, S. Ammoniacal process for the manufacture of carbonates of soda. CA7019 (A), January 24, 1877.

(3) Trypuc, M.; Bialowicz, K. $\mathrm{CaCO}_{3}$ production using liquid waste from Solvay method. J. Cleaner Prod. 2011, 19, 751-756.

(4) http://www.societechimiquedefrance.fr/extras/Donnees/mine/naco/texnaco.htm (accessed February 24, 2015).

(5) Hyman, M. Guidelines for national waste management strategies: moving from challenges to opportunities. 2013, (http://www.unep.org/ietc/Portals/136/Publications/Waste\%20Management/UNEP\%20NWMS\% 20English.pdf) (accessed April 23, 2015).

(6) Ozdemir, S.; Bardakci, T. Hydrogen sulfide removal from coal gas by zinc titanate sorbent. Separ. Purif. Technol. 1999, 16, 225-234.

(7) Montes, D.; Tocuyo, E.; González, E.; Rodríguez, D.; Solano, R.; Atencio, R.; Ramos, M. A.; Moronta, A. Reactive $\mathrm{H}_{2} \mathrm{~S}$ chemisorption on mesoporous silica molecular sieve-supported $\mathrm{CuO}$ or ZnO. Micropor. Mesopor. Mat. 2013, 168, 111-120.

(8) Yamamoto, T.; Tayakout-Fayolle, M.; Geantet, C. Gas-phase removal of hydrogen sulfide using iron oxyhydroxide at low temperature: Measurement of breakthrough curve and modeling of sulfidation mechanism. Chem. Eng. J. 2015, 262, 702-709.

(9) Cullis, C. F.; Hirschler, M. M.; Atmospheric sulphur: natural and man-made sources. Atmospheric Environment 1980, 14, 1263-1278. 
(10) Bates, T. S.; Lamb, B. K.; Guenther, A.; Dignon, J.; Stoiber, R. E. Sulfur emissions to the atmosphere from natural sources. J. Atmospheric Chem. 1992, 14, 315-337.

(11) Wang, J.; Zhang, Y.; Han, L.; Chang, L.; Bao, W. Simultaneous removal of hydrogen sulfide and mercury from simulated syngas by iron-based sorbents. Fuel 2013, 103, 73-79.

(12) Arena, U. Process and technological aspects of municipal solid waste gasification. A review. Waste Management 2012, 32, 625-639.

(13) Woolcock, P. J.; Brown, R. C. A review of cleaning technologies for biomass-derived syngas. Biomass Bioenergy 2013, 52, 54-8 4

(14) Pham Minh, D.; Gallezot, P.; Besson, M. Degradation of olive oil mill effluents by catalytic wet air oxidation 1. Reactivity of p-coumaric acid over Pt and Ru supported catalysts. Appl. Catal. B: Env. 2006, 63, 68-75.

(15) Escardino, A.; Garcia-Ten, J.; Feliu, C. Kinetic study of calcite particle (powder) thermal decomposition: Part I. J. European Ceram. Soc. 2008, 28, 3011-3020.

(16) Huang, C. C.; Chen, C. H.; Chu, S. M. Effect of moisture on $\mathrm{H}_{2} \mathrm{~S}$ adsorption by copper impregnated activated carbon. J. Hazard. Mat. B 2006, 136, 866-873.

(17) Nassar, N. N.; Husein, M. M.; Pereira-Almao, P. Ultradispersed particles in heavy oil: Part II, sorption of $\mathrm{H}_{2} \mathrm{~S}_{(\mathrm{g})}$. Fuel Proc. Technol. 2010, 91, 169-174.

(18) Wu, M.; Hu, C.; Feng, Y.; Fan, H.; Mi, J. Microwave effects on the structure of $\mathrm{CeO}_{2}$-doped zinc oxide sorbents for $\mathrm{H}_{2} \mathrm{~S}$ removal. Fuel 2015, 146, 56-59.

(19) Davydov, A. A.; Marshneva, V. I. Marina.; Shepotko, L. Metal oxides in hydrogen sulfide oxidation by oxygen and sulfur dioxide I. The comparison study of the catalytic activity. Mechanism of the interactions between $\mathrm{H}_{2} \mathrm{~S}$ and $\mathrm{SO}_{2}$ on some oxides. Appl. Catal. A: Gen. 2003, 244, 93-100. 
(20) Othman, M. A.; Zahid, W. M.; Abasaeed, A. E. Selectivity of layered double hydroxides and their derivative mixed metal oxides as sorbents of hydrogen sulfide. J. Hazard. Mat. 2013, $254-255,221-227$.

(21) Nguyen-Thanh, D.; Block, K.; Bandosz, T. J. Adsorption of hydrogen sulfide on montmorillonites modified with iron. Chemosphere 2005, 59, 343-353.

(22) Hongrapipat, J.; Yip, A.C.K.; Marshall, A.T.; Saw, W. L.; Pang, S. Investigation of simultaneous removal of ammonia and hydrogen sulphide from producer gas in biomass gasification by titanomagnetite. Fuel 2014, 135, 235-242.

(23) Pham Minh, D.; Aubert, G.; Gallezot, P.; Besson, M. Degradation of olive oil mill effluents by catalytic wet air oxidation: 2-Oxidation of p-hydroxyphenylacetic and p-hydroxybenzoic acids over Pt and Ru supported catalysts. Appl. Catal. B: Env. 2007, 73, 236-246.

(24) Galera Martínez, M.; Pham Minh, D.; Weiss-Hortala, E.; Nzihou, A.; Sharrock, P. Synthesis, characterization, and thermo-mechanical properties of copper-loaded apatitic calcium phosphates. Composite Inter. 2013, 20, 647-660.

(25) Bagreev, A.; Rahman, H.; Bandosz, T. J. Thermal regeneration of a spent activated carbon previously used as hydrogen sulfide adsorbent. Carbon 2001, 39, 1319-1326.

(26) Cal, M.P.; Strickler, B.W.; Lizzio, A.A; Gangwal, S.K. High temperature hydrogen sulfide adsorption on activated Carbon II. Effects of gas temperature, gas pressure and sorbent regeneration. Carbon 2000, 38, 1767-1774.

(27) Fang, H. B.; Zhao, J. T.; Fang, Y. T.; Huang, J. J.; Wang, Y. Selective oxidation of hydrogen sulfide to sulfur over activated carbon-supported metal oxides. Fuel 2013, 108, 143148. 
(28) Sahu, R. S.; Patel, R.; Ray, B. C. Removal of hydrogen sulfide using red mud at ambient conditions. Fuel Proc. Technol. 2011, 92, 1587-1592. 